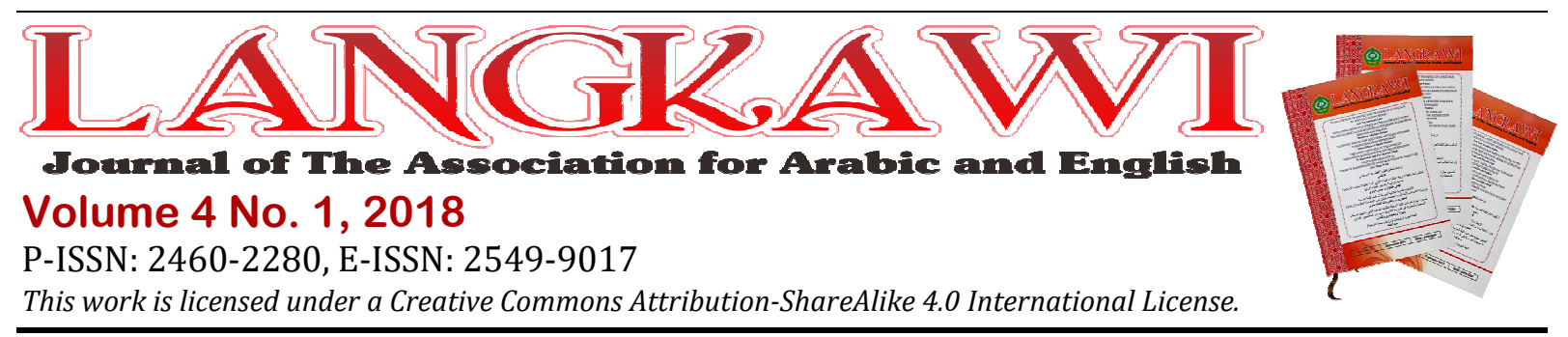

\title{
Teaching Writing to EFL Learners: An Investigation of Challenges Confronted by Indonesian Teachers
}

\section{Kuni Hikmah Hidayati ${ }^{1}$}

1 Universitas Negeri Surabaya, Indonesia. E-mail: kunihikmah@gmail.com

\begin{tabular}{l} 
ARTICLE INFO \\
\hline Keywords: \\
Teaching writing; internal \\
factors; external factors \\
How to cite: \\
Hidayati, K. H., (2018). \\
Teaching Writing to EFL \\
Learners: An Investigation \\
of Challenges Confronted \\
by Indonesian Teachers, \\
4(1), 21-31. \\
\\
DOI: \\
http://dx.doi.org/10.31332/ \\
lkw.v4i1.772
\end{tabular}

\begin{abstract}
Teaching English writing skill which involves developing linguistic and communicative competence of learners is considered a challenging task. When teaching writing, therefore, EFL teachers in general and Indonesian teachers in particular encounter many challenges (i.e. difficulties). This study aims to find out Indonesian teachers' challenges in teaching English writing skill and discuss possible solutions to remove, or at least, minimize, the problems. The data was collected by interviewing 10 English teachers who come from different part of East Java, Indonesia and teach English in either private or public Junior and Senior High Schools. The instrument used was structured interview. The data collected from the interview was, then, analyzed descriptively. The findings show that there are internal and external factors contribute to the challenges that the teachers confront. The internal factors include linguistic competence, native language interference, motivation and reading habits of the learners, while the external ones include the class condition, aids available for teaching writing and the availability of time. The research findings would facilitate the teachers and the concerning authorities to improve the ELT especially in teaching writing.
\end{abstract}

\section{Introduction}

To become competent users of English, one must focus on both productive and receptive skills. Writing and speaking are the productive skills, while listening and reading are the receptive skills. All skills are in fact important regarding communication. However, Browker (2007) argues that writing, in particular, is a skill that is required in many contexts throughout life. For instance you can write an email to friends either local or overseas, or write essays for your homework. In school, writing is a way of life with which learners pass the course; "without some ability to express yourself in writing, you don't pass the course" (Brown, 2000, p. 339). It is also the most used skill in evaluating students' performance in almost all levels of education (Afrin, 2016). More importantly, for Indonesian learners notably, writing English skill (i.e. writing essays) is one of requirements for someone to get a scholarship (e.g. LPDP) and even a job.

Taking into account the importance of writing, however, many EFL teachers found teaching writing is difficult (Thuy, 2009). This is to say that there are challenges of teaching writing to EFL learners. Indeed, teaching English writing skills 
involves developing linguistic and communicative competence of the learner which makes it quite a challenging task (Bilal, Tariq, Din, Latif, \& Anjum, 2013). However, teachers are assumed to have a professional responsibility for learners' writing development. To do this, they are assumed to have proficiency in the L2, knowledge about writing and the local curriculum, and a repertoire of relevant techniques for responding to their students' writing (Leki, Cumming, \& Silva, 2008, p. 83).

Some works has been done in the area of teaching writing to EFL students, responding to the difficulties of teaching writing. For instance, a study conducted in Palestine focusing on criticizing teachers' traditional methods in teaching writing (Abas \& Bakir, 2013). They found that using traditional methods results passive and monotonous classroom activities. Instead, they suggested blended writing activities being integrated as part of the blended learning outcome. Another study found out that using STAD (Student Team Achievement Divisions) is an effective method to teach writing to Thai learners (Mustika, 2016). In Pakistan, a study investigated teachers' problems in teaching writing to students in urban and rural area was conducted (Bilal, Tariq, Din, Latif, \& Anjum, 2013). The result of the study suggested that the classroom activities should pay more attention on controlled writing.

Other studies on writing have also been conducted in Indonesia. Most of which focused on either traditional or modern techniques to teach writing, such as a technique called TPS (Think-Pair-Share) which was found sufficient (Sumarsih \& Sanjaya, 2013). Also, there is a study investigating Indonesian teachers' familiarity with Internet-based teaching of writing (Cahyono \& Mutiaraningrum, 2016). The result of the study was that Indonesian EFL teachers valued the Internet-based teaching of writing as this practice benefits the students regarding their writing quality and quantity, autonomy, flexibility, as well as confidence.

Much has been written about the teaching of writing. However, most of the literature in the field is concerned with either modern or traditional techniques to teach writing, and not many writers focus on what challenges teachers confront and how to deal with them. Therefore, this study is both to place more emphasis on challenges to the actual teaching and learning process of writing and to discuss possible solutions to help overcome them.

Investigating the teachers' challenges of teaching writing becomes important to see the current and future demand for a good writing skill. "Students with poor English writing skills may lag behind in their academic and professional career (Bilal, Tariq, Din, Latif, \& Anjum, 2013). The results of the study are important in picturing the Indonesian EFL teachers' formidable challenges in teaching writing and are pertinence to Indonesian educational quality, especially in teaching writing. By interviewing Indonesian teachers towards their teaching writing experience, this study is questioning on what are teachers' challenges of teaching writing to EFL learners? And to respond to the first research question, another question arises; what are possible solutions overcoming teachers' challenges of teaching writing to EFL learners? This study, therefore, aims to portrait Indonesian EFL teachers' challenges of teaching writing. 


\subsection{Literature Review}

a. The Concept of Writing

Writing is a process of communicating with others in which a writer sends his ideas and thoughts in written forms to readers. It is a process of thinking which the writer discovers, organizes, and communicates his or her thoughts to the reader (Wingersky, 1999, p. 4). Moreover, it is about conveying meaning by using words that have been chosen and put together in written or printed form (Farbrain \& Whinch, 1996, p. 32). All in all, writing means sending information and expressing ideas through written forms. In short, writing is a tool of communication in written form.

Learning to write either in the first or second language is one of difficult tasks a learner encounter (Richard, 1990, p. 100). Not only for those learning English as either foreign or second language it is difficult for the native speakers as well (Esmeralda, 2013). In fact, a good writing has to consider some aspects of writing; grammar, vocabulary, mechanic, content, and organization (Hartfiel, Hughey, Wormuth, \& Jacobs, 1985, p. 89). Grammar is a set of rules that help the students to construct sentences that make sense and are in acceptable English (Farbrain \& Whinch, 1996, p. 108). Vocabulary has something to do with the English words learners choose to express their ideas in their writing. Moreover, Organization is learners' ability to arrange their ideas into logical coherence and cohesion to make a unified paragraph (Hartfiel, Hughey, Wormuth, \& Jacobs, 1985, p. 93).

\section{b. Teaching Writing}

Since 1980s, a great deal of theoretical works have been done on the nature of L2 writing and learning (Brown, 2000, p. 334). This study focuses on the teaching of writing which can be discussed regarding 'the role of the teacher' and 'the principles of designing writing performance'.

c. The Role of the Teacher

The role of the teacher in teaching writing is discussed in the area of CLT. "It is an appropriate locus for process of writing due to its emphasis on learner-centered instruction, student-student negotiation, and strategies-based instruction that valuesthe variability of learners' pathways to success" (Brown, 2000, p. 340). The role of the teacher, therefore, has to be one of facilitator and coach, not an authoritative arbiter. As a facilitator, the teacher offers guidance in helping students to engage in the thinking process of composing but, in a spirit of respect for student opinion, must not impose his or her thoughts on student writing (Brown, 2000, p. 340).

\section{d. Influential Factors of Learners' EFL Writing Ability}

There are several factors that influence one's EFL writing ability:

\section{1) English competence}

English competence is a broad term which, regarding writing, might include learners' grammatical competence, vocabulary mastery, and how to organize a good paragraph of English (Brown, 2004, p. 233). Lack of either grammar competence or vocabulary in particular, makes learners difficult to produce not only a paragraph but also a sentence, even. "Learners engage in a productive task can become very 
frustrated when they just do not have the words or the grammar they need to express themselves" (Harmer, 2001, p. 252).

\section{2) Native language interference}

Learner's native language is closely related to their English competence regarding their influence to learning to write English. Native language, therefore, is also seen as a very influential factor towards the success of a learner's writing in EFL (Harmer, 2001, p. 250). In this context, the learners' native language is Indonesian. When Indonesian brings good impacts towards a certain aspect of the learners' writing, this is called as 'transfer'. Otherwise, when it brings bad impacts, this is called 'interference'. About writing, Indonesian interferences towards writing English are concerning morphology, semantics and syntax.

\section{3) Motivation and Reading habit}

Some learners are not particularly concerned about their writing, while others are. The extent to which learners' intrinsic motivation propels them toward improvement will impact their reading habits as well. The teacher does not have other choice except to try to wake learners' motivation. The problem is that motivation is a very complex thing. Motivation means a cluster of factor that 'energizes' the behavior and gives it 'direction' (Atkinson, 2002). Reading habit which is known to be much related to someone's writing ability also need attention.

\section{Method}

\section{a. Research Subject}

The study involved ten (10) Indonesian EFL teachers who come from different part of East Java, Indonesia and teach in either public or private Junior and Senior High Schools (see Appendix A). They were male and female teachers of five (5) selected Senior High Schools and another five (5) Junior High Schools. They were chosen randomly considering the urban and rural area of the schools. The lengths of their teaching English vary from three (3) to seven (7) years. They were interviewed separately regarding their experiences (esp. challenges) in teaching writing.

\section{b. Technique of Data Collection and Analysis}

The data was collected from Indonesian EFL teachers through structured interviews. They were interviewed separately regarding their experiences (esp. challenges) in teaching writing. They were asked the same main questions during the interview. The interviewer was the researcher. This is in fact proposed that in a qualitative research, the researcher was as a key instrument collecting the data (Krippendorf, 1987, p. 85).

\section{c. Teacher Interviews}

Ten (10) Indonesian EFL teachers coming from ten (10) different Senior and Junior High Schools were interviewed; the aspect of the interview relevant to this study was the discussion of their teaching writing challenges. The interviewer invited the teachers to reflect on the writing activities in the class, the teaching strategies used, and the learning achieved in the lesson; drawing on the notes. The teachers were also invited to consider what difficulties their students face in writing. More importantly, they were invited to reflect what factors may disturb them while 
teaching English writing skills and what solutions they probably had tried to resolve the difficulties. After the data was collected, it was analyzed descriptively.

\section{Findings and Discussion}

The findings are described regarding the English teachers' experiences in teaching writing and the challenges they confront during the teaching of writing.

\section{a. English Teachers' Experiences in Teaching Writing}

Towards the question of what writing activities learners mostly perform in the classroom, the teachers mostly ask the learners to perform vary, all of which are related to genres of text such as report, recount, narrative and so on. Half of the subjects who mostly teach in Senior High School ask them to make a text in a form of controlled writing activities in the end of the writing class. Another half, however, tend to follow what is in the LKS and ask the learners to practice the writing in it such as filling up blanks, making sentences in a grammatical way, etc. Moreover, concerning time allocation for developing students' English writing skill by practicing in each period, among the ten (10) teachers, $30 \%$ of them give 25 to 30 minutes for writing practice on daily basis while $20 \%$ provide approximately 15 minutes only; to do a brainstorming, simple practice, etc. Only $10 \%$ give 40 minutes and $40 \%$ give no time for writing practice at all.

Also, teaching strategies or techniques that the teachers adopt for teaching writing vary. $30 \%$ of the subjects clearly mention GTM (Grammar Translation Method) is as the method they often use to teach writing. 40\% use both GTM and DM (Direct Method). The rest of the subjects use techniques like brainstorming, mind-mapping, etc. Besides, some teachers mentioned some aids used to teach writing. They have either audio or video aids available in each classroom. Among those having such A/V aids available, however, only a half of them make use of the aids. Another half seldom or never use them in teaching writing. Nevertheless, the rest of the subjects do not use any aids unless white board and books because there are only white boards and books available; most of which are those teaching in rural area.

The main discussion on whether writing is challenging, $90 \%$ of the subjects say that teaching writing is challenging due to several factors such as the class condition, the aids they can use for teaching and the availability of time the students can practice. They also mention several factors of the students' themselves, such as the students' linguistic competence, motivation and their low reading habit. Another $10 \%$ say that teaching writing is neither easy nor challenging compared to teaching writing. She found teaching speaking is more challenging than teaching writing. The students' performance was also discussed, related to the challenges. All of the subjects have the same answer that the learners writing ability in general are mostly poor. Those who are teaching in rural area notably found that at least $80 \%$ of their learners in a class have difficulties in linguistic competence such as lack of grammar and vocabulary mastery. Meanwhile, those who are in urban area admit that some learners are quite competent in writing, especially those who are in Senior High School. Those who are in Junior High School in urban area found that some students have quite good linguistic competence but very poor sentence structure ability. 


\section{b. English Teachers' Challenges in Teaching Writing}

The study found that there are two factors that contribute to the teachers' challenges in teaching writing. The first factors are internal factors, which in fact contribute a lot to the challenges. The internal factors mean those coming from the learners. They are such as their native language interference (i.e. Indonesian language), their English competence (e.g. linguistic competence such as grammar knowledge, vocabulary mastery), motivation, and reading habit. Meanwhile, there are also external factors contributing to the challenges. The external factors are such as the class condition, the aids available for teaching, and the availability of time.

The following chart shows internal factors that contribute to the teachers' challenges in teaching writing:

\section{Internal Factors}

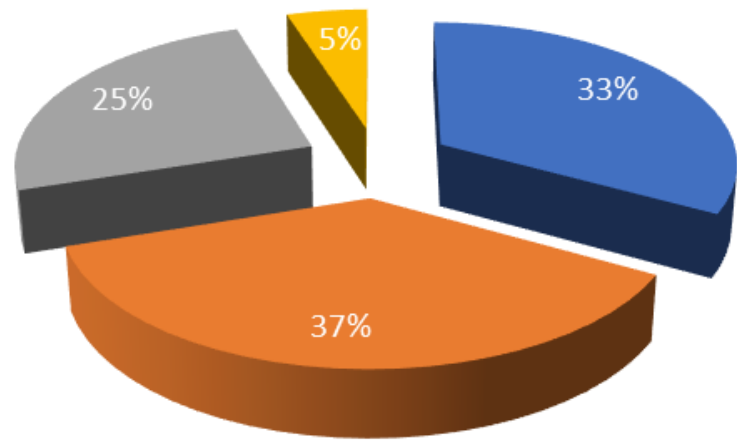

- Native Language Interference

anglish Competence

Motivation

Reading Habit

Figure A. Internal Factors of Learners Contributing to Teachers' Challenges in Teaching Writing

Figure A shows that the learners' low English competence is seen to be the most influential factor towards the teachers' challenges in teaching writing, which can be portrayed as $37 \%$ among other factors. The second most influential factor $(33 \%)$ is the fact that their native language (i.e. Indonesian) influence cannot be separated from their learning EFL. Finally, another 30\% of the factors contributing to the teachers' challenges in teaching writing are the learners' motivation and their low reading habit.

\subsection{Discussion}

From ten (10) EFL teachers involved in this study, those who teach in either rural or urban area perceive teaching writing to be a quite challenging task. To discuss what factors contribute to the challenges, this study has found out that there are several factors which can be divided into internal and external factors. Internal factors mean those that appear to be the learners'. There are four internal factors will be discussed; native language interference (i.e. Indonesian language), English competence (e.g. linguistic competence such as grammar knowledge, vocabulary mastery), motivation, and reading habit. In addition to the internal factors, there are other factors 
like the class condition, the aids available for teaching, and the availability of time, which are known as external factors in this study.

a. English competence

English competence appears to be the most influential factor regarding the teachers' challenges when teaching writing. It is portrayed by the $37 \%$, which is the most comparing to another three factors, contributing to that. The ten (10) teachers indeed found this factor to be the most challenging one to teaching writing to the learners in their writing class. The discussion of how English competence of learners might contribute to one of the teachers' challenges will be pertained regarding each competence such as grammar, vocabulary etc.

English competence is a broad term which, regarding writing, might include learners' grammatical competence, vocabulary mastery, and how to organize a good paragraph of English (Brown, 2004, p. 233). Indeed, words (i.e. vocabulary) are the basic tool for writing, because words carry meaning for a writer to convey the message. Moreover, Grammar competence helps learners to construct sentences that make sense and are in acceptable English (Farbrain \& Whinch, 1996, p. 108). Likewise, knowledge of how to make a good paragraph helps learners to produce an acceptable English text. Lack of either grammar competence or vocabulary in particular, makes learners difficult to produce not only a paragraph but also a sentence, even. "Learners engage in a productive task can become very frustrated when they just do not have the words or the grammar they need to express themselves" (Harmer, 2001, p. 252).

This factor of learners' English competence contributes to teachers' challenges in teaching writing when the teachers cannot be 'sensitive' towards their students' competence. First of all, they do not recognize their learners' level of language and, second of all, they give them task which the learners' found difficult to do. Regarding the learners' vocabulary mastery, the teachers are supposed to adjust with the learners' level by freeing them to choose any topics they are interested in, so that they can find the topic whose vocabulary they are familiar with (Harmer, 2001, p. 251). Regarding grammar, also, the teachers are supposed to make the learners familiar with such grammatical features needed to make a certain genre of the text the students will make. By this way, the teachers' challenges will be resolved since they can adjust the task with the students' level.

\section{Native language interference}

Learner's native language is closely related to their English competence regarding their influence to learning to write English. Native language, therefore, is also seen as a very influential factor towards the success of a learner's writing in EFL (Harmer, 2001, p. 250). In this context, the learners' native language is Indonesian. When Indonesian brings good impacts towards a certain aspect of the learners' writing, this is called as 'transfer'. Otherwise, when it brings bad impacts, this is called 'interference'.

The study has found out that Indonesian interference towards English' writing ability of learners contributes a lot to teachers' challenge in teaching writing in class (i.e. $33 \%$ as seen in the figure). Of the ten (10) teachers, most of them mention that the learners mostly found difficult towards aspects of English which are different from 
those of Indonesian. About writing, Indonesian interferences towards writing English are concerning morphology, semantics and syntax.

Morphologically, Indonesian and English have similarities as well as differences. Such differences are those making the Indonesian learners difficult composing English writing. For instance, "Indonesian verbs are not marked for person, tense, or number...there is no distinction between simple past and present perfect, meaning there is no equivalent in the Indonesian language" (Menard, 2010). E.g. "He eat right now." or He is eat at this time." Also, Indonesian has no verb form of past (i.e. past tense), therefore, it is difficult; Indonesian might say "I write a letter yesterday or I finished written the letter". "Future time is more a syntactical and morphological error combined (Menard, 2010). E.g. "This book we will buy." "Akan" is the word in Indonesian representing future time. The sentence is the same structure (i.e. word-by-word translation) of Indonesian "buku ini kita akan beli".

Also, 'spelling' is also often found to be a problem; "one of the reasons that spelling is difficult for students of English is that the correspondence between the sound of a word and the way it is spelt is not always obvious" (Harmer, 2001, p. 256). Thus, Indonesian learners might spell words phonetically, as in their language all words are spelled that way. This problem of spelling, in fact, is found to be more challenging to the teachers who teach in Junior High School, while other morphological problems are found in either Junior or Senior High School. Regarding Semantic, Indonesian learners have difficulty distinguishing pairs of English words that have a single word equivalent.

a) "take/send/pickup" e.g. "She takes her son after school"

b) "hear/listen" e.g. "I listened a sound in the dark."

Another challenge the teachers confront regarding their learners is the syntax issues. They are:

a) Indonesian learners are mostly accustomed to S-V-O order, even when asking question; "kamu suka nasi goreng?" (Indonesian spoken). Therefore, they would say "you like fried rice?" instead of "do you like fried rice?" (Indonesian has no equivalent word for 'do').

b) Relative pronoun issues. There is only one word in Indonesia that is used (i.e. yang) whereas we have many. E.g. "The letter that I haven't received it yet." (duplicated personal pronouns)

c) As in reflexive pronouns, Indonesian learners of English only have one word for "self" (diri) so mistakes such as "Ali hurt heself" or "They cook for theirselves." etc. might be very common.

d) Regarding using "it" and "there" the equivalent in Indonesian is "ada" which is "got/has/be" so an example of an error would be, "Was an exam last week."

e) The Indonesian language does not have articles, so they are often dropped when learning English. For instance, "How was exam?" The "the" was dropped because the thought came across without the extra word. 
Afterwards, the study concludes that native language of learners will be a problem (challenge) in teaching writing English, if the teacher cannot understand the fact and decided a way to solve the condition.

b. Motivation and Reading habit

The influence of learners' low motivation and reading habit that the teachers confront is discussed as one point since both are closely related. In fact, some learners are not particularly concerned about their writing, while others are. The extent to which learners' intrinsic motivation propels them toward improvement will impact their reading habits as well. Reading habit which is known to be much related to someone's writing ability also need attention. Thus, in terms of motivating learners to write and read in English, teacher can help learners to perceive or develop their motivation by showing, among other things, how writing in English is significant in shaping their self image and ultimately in reaching some of their higher goals in the future (i.e. to get a scholarship, to get a good job).

c. External factors

The challenges of teaching writing does not only come from internal aspects of the learners that the teachers confront but also influenced by external factors. The external factors which are found to be the most influential ones, from the interview, are the class condition, the aids available and the availability of time when teaching writing.

Class condition refers to the fact that most Indonesian classes are a large class, consisting of many students in a class. Teaching learners at large class is always debatable, especially for countries that use English as a Foreign Language (EFL). Some challenges faced at large class are space problem for both teacher and students such as physical discomfort, intimidating atmosphere, giving individual attention becomes difficult for the teacher, and teacher's feedback is not proper enough and the teacher feels guilty. To convert the difficulties in having large class, the teacher need to focus on learners' need. Teacher needs to have an open mind to be innovative to help the learners attain success in writing.

Another problem appears to be the teachers' challenge is the availability of aids for teaching and that of time. Of the ten (10) teachers mention that they hardly use any aids to teach the learners. Most of them use only a piece of paper for the learners to write on, while to explain everything, they use blackboard and board marker only. Some of them admit that there are audio visual aids available in the school but they never use them to teach writing. More importantly, the availability of time is another external factor the teachers cannot deny. They explained that the students need longer time to practice than the school provide. This is because they need to explain the learners what to write first, ask the students to practice writing and assess their writing in the end.

\section{d. Solutions}

As mentioned in the previous discussion, there are some factors why teachers find teaching writing challenging, especially for Indonesian teachers. However, there are some ways in which teachers can do to overcome the challenges. In the first place, the teachers need to match the tasks that they ask the learners to perform with their language level. This means ensuring that they have the minimum language 
they would need to perform such a task. Secondly, the teachers need to ensure that there is a purpose to the task and that learners are aware of this. The last but not least, the teachers should remember that learners need to be helped or guided during the process of learning to write.

\section{Conclusion}

To date, this study is the first to investigate teachers from different part of East Java regarding their challenges of teaching writing. Challenges in teaching writing are complex. It is not only related with the learners' factors but also external ones. In the internal factors, the challenges are related with native language, linguistic competence, and motivation. Those problems are related with condition of the learners. The external challenges are teaching writing at large class and the availability of aids and time. Based on the challenges above, it suggests the teacher: In the first place, the teachers need to match the tasks that they ask the learners to perform with their language level. This means ensuring that they have the minimum language they would need to perform such a task. Secondly, the teachers need to ensure that there is a purpose to the task and that learners are aware of this. The last but not least, the teachers should remember that learners need to be helped or guided during the process of learning to write.

\section{References}

Abas, D., \& Bakir, A. (2013). Writing Difficulties and New Solutions: Blended Learning as an Approach to Improve Writing Abilities. International Journal of Humanities and Social Science, 3 (9), 254-266.

Afrin, S. (2016). Writing Problems of Non-English Major Undergraduate Students in Bangladesh: An Observation. Open Journal of Social Sciences, 104-115.

Atkinson, R. K. (2002). Optimizing Learning from Examples Using Animated Pedagogical Agents. Journal of Educational Psychology.

Bilal, H. A., Tariq, A. R., Din, N. u., Latif, H., \& Anjum, M. N. (2013). Investigating the Problems Faced by the Teachers in Developing English Writing Skills. Asian Journal of Social Sciences and Humanities, 2 (3), 238-244.

Browker, D. N. (2007). Academic Writing: A Guide to Tertiary Level Writing. New Zealand: Massey University.

Brown, H. D. (2004). Language Assessment: Principles and Classroom Practices. New York: Longman.

Brown, H. D. (2000). Teaching by Principles (2nd Edition ed.). San Francisco: Longman.

Cahyono, B. Y., \& Mutiaraningrum, I. (2016). Indonesian EFL Teachers' Familiarity with and Opinion on the Internet-Based Teaching of Writing. English Language Teaching, 9 (1), 199-208.

Esmeralda, C. (2013). An Analysis of the Wtiring Skill Difficulties of the English Composition I Students. Arts and Sciences Journal, 1-14.

Farbrain, G., \& Whinch. (1996). Reading, Writing and Reasoning. Boston: Houghton Mifflin Company. 
Fraenkel, J. R., \& Wallen, N. E. (2006). How to Design and Evaluate Research in Education. New York: McGraw - Hill.

Harmer, J. (2001). The Practice of English Language Teaching (3rd Edition ed.). Pearson Education Ltd.

Hartfiel, Hughey, Wormuth, \& Jacobs. (1985). Learning ESL Composition. Rowley: Newbury House Publisher, Inc.

Krippendorf, K. (1987). Content Analysis: An Introduction to Methodology. London: Sage Publication Beverly Hills.

Leki, I., Cumming, A., \& Silva, T. (2008). A Synthesis of Research on Second Language Writing in English. New York: Routledge.

Menard, R. (2010). Interference of Indonesian Language in learning English. Teaching English as a Second Language.

Mustika, N. (2016). Improving Students' Descriptive Writing Ability Using STAD In Pirayanawin Klonghin Wittaya School. Journal of English, Linguistic, Literature, Information, Teaching and Education, 1 (1), 39-48.

Richard, J. C. (1990). The Language Teaching Matrix. New York: Cambridge University Press.

Sumarsih, \& Sanjaya, D. (2013). TPS as an Effective Technique to Enhance the Students' Achievement on Writing Descriptive Text. English Language Teaching, 6 (12), 106-113.

Thuy, N. H. (2009). Teaching efl writing in Vietnam: Problems and solutions - a discussion from the outlook of applied linguistics. Journal of Science, Foreign Languages, 61-66.

Wingersky. (1999). Writing Paragraph and Essays Integrating Reading, Writing and Grammar Skills. London: Wadsworth Publishing Company. 